\title{
ASMS News
}

\section{THE 8TH SANIBEL CONFERENCE}

The 8th Sanibel Conference on Mass Spectrometry, Metal-Containing Ions and Their Applications in Mass Spectrometry, organized by Jonathan Amster and Jennifer Brodbelt, will be held January 20-23, 1996, on Sanibel Island, Florida. The 1996 Sanibel Conference will focus on recent developments involving metalcontaining ions and their applications in mass spectrometry. The study of metal ions, their analysis, interactions, and reactions, has proved to be one of the most exciting areas of gas-phase chemistry in recent years.

The growth in the understanding of fundamental aspects of metal ion reactivity has promoted the application of metal chemistry to structural elucidation of biological molecules such as peptides and sugars, and allowed new inroads into the evaluation of cluster chemistry, including aspects of solvation. With the advent of electrospray ionization, even metal/protein interactions have begun to be studied. In addition to the emphasis on these topics, the latest advances in state-selective metal ion chemistry, atomic analysis, and gas-phase molecular recognition will be discussed. The program will include invited speakers and contributed posters covering the chemistry of metalcontaining ions in the gas-phase and in solution as probed by mass spectrometry. Contributed posters are invited in the areas of ion-molecule chemistry, metallobiochemistry, state-specific chemistry, organometallic chemistry, and novel instrumentation developed for such studies.

The objective of this conference is to promote the exchange of ideas about metal-containing ions and their chemistry from both fundamental and analytical perspectives. The selected speakers will help to stimulate the exchange of ideas across several fields. For further information, please contact ASMS, 1201 Don Diego Avenue, Santa Fe, NM 87505. Telephone: (505) 989-4517.

\section{TH ASMS CONFERENCE ON MASS SPECTROMETRY}

The 44th ASMS Conference on Mass Spectrometry and Allied Topics, May 12-16, 1996, will be held at the Oregon Convention Center in Portland. The conference will begin Sunday afternoon, May 12, with tutorial sessions and a reception. Each day will feature a plenary lecture, followed by morning oral sessions, luncheon workshops, poster sessions, and afternoon oral sessions. All conference activities will be held at the Convention Center.

PII 1044-0305(96)00002-3
Conference participants will have a choice of hotels near the Convention Center, as well as in downtown Portland. There is a substantial number of rooms in the $\$ 60-\$ 80$ price range, as well as deluxe accommodations running $\$ 100-\$ 120$. The Portland Convention Bureau will coordinate room reservations. Portland has a light rail system which provides convenient transportation between downtown Portland and the Convention Center.

Abstract submission must be by diskette using software supplied by ASMS. The diskettes will be mailed to all members of ASMS. The deadline for receipt of abstracts on diskette is January 17, 1996. Abstract diskettes received late will not be accepted.

Conference calendar:

January 17 Deadline for RECEIPT of abstractsAbstracts must be submitted using software provided by ASMS.

March 30 Deadline for payment of dues to obtain member registration rate for the conference and short courses

April 12 Deadline for receipt of advance registrations

May 11-12 ASMS Short Courses

May 12-16 Conference

\section{ASMS SHORT COURSES}

Five short courses will be offered Saturday and Sunday, May 11-12, immediately preceding the ASMS conference. The courses are as follows:

"Interpretation of Mass Spectra," organized by the Washington/Baltimore Mass Spectrometry Discussion Group

"LC/MS: The Art and the Practice," organized by Alfred L. Yergey and Robert D. Voyksner

"Practical MS/MS," organized by Jodie V. Johnson and Richard A. Yost

"Introduction to Ion Optics and SIMION," organized by David A. Dahl and Anthony D. Appelhans

"Mass Spectrometry-Approaches to Characterizing Peptides and Proteins," organized by Daniel B. Kassel, John Stults, and Pierre Thibault

These courses will be held at the Red Lion Hotel Lloyds Center. For additional information, contact ASMS, 1201 Don Diego Avenue, Santa Fe, NM 87505. Telephone: (505) 989-4517. 